\title{
Postconflict Monetary Reconstruction
}

\author{
Christopher Adam, Paul Collier, and Victor A.B. Davies
}

\begin{abstract}
During civil wars governments typically resort to inflation to raise revenue. A model of this phenomenon is presented, estimated, and applied to the choices and constraints faced during the postconflict period. The results show that far from there being a fiscal peace dividend, postconflict governments tend to face even more pressing needs after than during war. As a result, in the absence of postconflict aid, inflation increases sharply, frustrating a more general monetary recovery. Aid decisively transforms the path of monetary variables in the postconflict period, enabling the economy to regain peacetime characteristics. Postconflict aid thus achieves a monetary "reconstruction" analogous to its more evident role in infrastructure. JEL codes: H56, F35, O10
\end{abstract}

War is expensive and so has powerful economic consequences. Civil war-now by far the most common form of war-is particularly damaging, reducing income, increasing capital flight, and diverting activity into subsistence. All of these effects can be expected to reduce the demand for money. The resulting decline in seigniorage revenue collides with increased government fiscal needs, with both effects tending to raise inflation. A likely economic legacy of war is thus a deterioration in the tradeoff between seigniorage and inflation. Just as the postwar government faces a hard choice between continued military spending and the reconstruction of infrastructure, so too it faces a choice between continued inflation and the "reconstruction" of the monetary base.

Section I of this article sets out the decision problems facing households and governments. The demand for money on the part of households is the constraint against which the government maximizes. Section II applies the model to the data. The expansion in data on civil wars has recently made it a researchable phenomenon using standard quantitative techniques (Miguel, Satyanath, and Sergenti 2004; Collier and Hoeffler 2004b). Estimates are made

Christopher Adam (corresponding author) is a research associate at the Centre for the Study of African Economies, Department of Economics, University of Oxford; his email address is christopher. adam@economics.ox.ac.uk. Paul Collier is the director of the Centre for the Study of African Economies; his email address is paul.collier@economics.ox.ac.uk. Victor A.B. Davies is a senior research economist at the African Development Bank and a research associate at the Centre for the Study of African Economies; his email address is v.davies@afdb.org.

THE WORLD BANK ECONOMIC REVIEW, VOL. 22, NO. 1, pp. 87-112

doi:10.1093/wber/lhm020

Advance Access Publication January 14, 2008

(C) The Author 2008. Published by Oxford University Press on behalf of the International Bank for Reconstruction and Development / THE WORLD BANK. All rights reserved. For permissions, please e-mail: journals.permissions@oxfordjournals.org 
of both how money demand is affected by civil war and its aftermath and how the revealed preferences of governments change when governments are faced with new constraints and needs. Potentially, the harsh policy tradeoffs that governments face in postconflict situations can be alleviated by aid-indeed, this is the context for which aid was invented. Section III introduces aid into the analysis, estimating how it affects constraints and choices and showing the path of inflation, money demand, and seigniorage with and without postconflict aid. Section IV discusses the policy implications of the results.

\section{The Government Decision}

Assume that before civil war, the government conducts its monetary policy on a sustainable basis. This may well involve the choice of a positive rate of inflation; it does not, however, involve the government attempting to fool private agents by delivering more inflation than they expect. The government is not assumed necessarily to try to maximize social welfare. The actual choice of inflation will depend on how costly it is to the government relative to other sources of revenue, where the costs taken into account by the government may differ from those that concern society.

Civil war takes the society and the government by surprise. This is a reasonable characterization because, although civil wars can to some extent be expected, no model has been able to predict the actual outbreak of civil war with any certainty: the main news occurs around the outbreak.

Consider the effect of the outbreak of civil war on private agents. Civil war reduces GDP growth. A typical estimate of the economic loss is that growth is reduced by about 2.3 percent over a period of seven years (Collier 1999). Heightened insecurity tends to divert economic activity toward relatively sheltered sectors, notably subsistence, and agents attempt to protect assets through capital flight. In the postconflict decade the economy usually recovers, but slowly, with GDP typically growing about 1.1 percent more than normal (Collier and Hoeffler 2004a). Hence, for a prolonged period, the demand for money is likely to be reduced both directly, as a result of the fall in income, and indirectly, as a result of activity and asset substitution.

The decline in the demand for money exacerbates the seigniorage-inflation tradeoff facing the government. However, the government will want to increase its spending for the duration of the conflict. Military spending typically increases by nearly 2 percent of GDP during civil war (Collier and Hoeffler 2007). This need for increased military spending raises the government discount rate. Because borrowing is difficult during civil war, the government chooses a higher rate of inflation.

This government's problem can be set out more formally using a simple model in which a forward-looking government chooses how much conflict-related expenditure is to be financed at the margin through seigniorage. The model, built around a simple Cagan (1956) characterization of the private 
sector's demand for money, is similar to that found in Bruno and Fischer (1990), Adam (1995), and Marcet and Nicolini (2003).

A number of simplifying assumptions are made to sharpen the exposition. First, and least important, private income and other sources of financing are held constant, except for the direct changes caused by war itself. The discussion thus abstracts from broader questions of the optimal fiscal response to expenditure shocks (see, for example, Mankiw 1987; Cashin, Ul Haque, and Olekalns 2002). ${ }^{1}$

Second, a simple monetarist framework is assumed, in which the authorities' monetary instrument is the volume of nominal base money, which is the only domestic financial liability. Money is held by both the bank and nonbank private sectors. In the empirical analysis seigniorage earned on currency in circulation is distinguished from seigniorage earned on bank reserves; without loss of generality the two are combined in the model presented in this section.

Third, the private sector's inflation expectations are assumed to be formed adaptively, albeit in a manner consistent with learning. Given the context, this has an intuitive appeal, because private agents could be expected to respond with a lag, possibly a very short one, to conflict-related changes in public expenditure. Employing an adaptive expectations framework has other merits. Specifically, given the Cagan-form money demand function, inflation equilibria on the "good side" of the seigniorage Laffer curve are dynamically stable under the assumption of adaptive expectations, whereas those on or above the top of the Laffer curve are unstable. As Bruno and Fischer (1990) show, the opposite holds under rational expectations, a feature that gives rise to the "high inflation trap" analyzed in their article. ${ }^{2}$ Given that the analysis here starts from a position at which the economy is in an initial equilibrium on the "good side" of the Laffer curve, it makes sense that this initial equilibrium is dynamically stable.

Finally, time-inconsistency problems are assumed away, in the strict sense that the initial and any subsequent long-run inflation equilibria are credible.

\section{The Model}

Government preferences are defined as

$$
V=V\left(g\left(\pi_{t}\right), k\left(\pi_{t}\right)\right)
$$

where $g$ denotes government expenditure, $\pi_{t}$ the inflation rate at time $t$, and $k\left(\pi_{t}\right)$ the discounted future costs of current inflation distinct from the inflationtax distortion on the demand for money. For example, $k\left(\pi_{t}\right)$ could reflect the reduction in investment efficiency associated with higher inflation. The model

1. Equivalently, the government's problem can be characterized in terms of the change in expenditure requirements net of other financing items.

2. This property of adaptive expectations is replicated under rational expectations if there is lagged adjustment of money demand. 
assumes that $V_{g}>0, V_{k}<0$, and $k^{\prime}\left(\pi_{t}\right)>0$. Both $g($.$) and k($.$) are measured$ as shares of GDP.

The government's period budget constraint in nominal terms is given by

$$
G_{t}=\Delta M_{t}+A_{t}+T_{t}
$$

where $M_{t}$ denotes the nominal base money, $\mathrm{A}_{t}$ the domestic value of aid inflows, and $T_{t}$ conventional tax revenues. Dividing through by nominal GDP, $Y_{t}=P_{t} y_{t}$, allows equation (2) to be expressed as

$$
g_{t}-a_{t}-\tau_{t}=\Delta m_{t}+\left(\frac{\pi_{t}}{1+\pi_{t}}\right) m_{t-1}
$$

where $g_{t}$ denotes the real value of government expenditure, $a_{t}$ real aid, $\tau_{\mathrm{t}}$ real conventional taxation, while the terms on the right side denote total seigniorage (consisting of the growth in real money balances plus the inflation $\operatorname{tax})$.

Aid and tax revenue are treated as fixed, so that at the margin, changes in government expenditure are financed by changes in domestic deficit financing. The private sector's demand for money is characterized by a Cagan money demand function of the form

$$
m_{t}=c_{t} y_{t} \exp \left(-\alpha \tilde{\pi}_{t}^{e}\right)
$$

where $c$ denotes a constant that may shift over time (in response to the onset or cessation of conflict, for example), $\pi_{t}^{e}$ denotes expected inflation, and $\tilde{\pi}_{t}^{e}=\pi_{t}^{e} /$ $\left(1+\pi_{t}^{e}\right) .^{3}$ Defined in this manner, the inflation term, $\tilde{\pi}_{t}$, is bounded above by 1 as the conventional measure of inflation becomes arbitrarily large, giving it a natural interpretation as a tax rate at which a value of 1 implies complete confiscation.

The private sector adjusts its inflation expectations, defined in terms of the inflation factor $\tilde{\pi}_{t}^{e}$, in response to the deviation of actual inflation from the level anticipated in the previous period:

$$
\dot{\tilde{\pi}}_{t}^{e}=\beta_{t}\left(\pi_{t}-\pi_{t}^{e}\right),
$$

where a dot $(\cdot)$ denotes the derivative with respect to time and $0<\beta_{t}<1$ measures the speed of adjustment, which could vary over time, as a result of learning, for example. See Marcet and Nicolini (2003) for a discussion of alternative learning algorithms. For the most part, $\beta_{t}$ is assumed to equal $\beta$.

3. Calvo and Leiderman (1992) show that under specific restrictions on functional form, equation (4) derives directly from the dynamic first-order condition for a representative agent maximizing utility of the form $U=\int_{t=0}^{\infty}\left[u\left(c_{t}\right)+v\left(m_{t}\right)\right] e^{-\rho t} d t$. 


\section{Equilibrium}

The government's problem is to maximize equation (1) subject to equations (2) and (4). Given the assumption that the government can credibly commit to a given inflation rate, in equilibrium inflation expectations are correct. Assuming no growth in real income, this implies a constant rate of inflation $\tilde{\pi}_{t+1}^{e}=$ $\tilde{\pi}_{t+1}=\tilde{\pi}_{t}$ and hence a constant growth rate of the money supply. From equation (5) it follows that $\dot{\tilde{\pi}}_{t+1}^{e}=0$. In these circumstances the first-order condition with respect to inflation is given by

$$
\frac{-V_{k} k^{\prime}\left(\tilde{\pi}_{t}\right)}{V_{g}}=m_{t}\left(1-\alpha \tilde{\pi}_{t}\right)
$$

The solution to equation (6) defines the optimal (constant) inflation rate, $\tilde{\pi}_{t}^{*}=\tilde{\pi}_{0}{ }^{*}$, and hence the optimal rate of growth of the money supply. Substituting equation (6) into equations (4) and (3) yields optimal seigniorage, shown as point $\mathrm{A}$ in figure 1 .

The right side of equation (6) is simply the slope of the seigniorage Laffer curve defined by the demand for money, equation (4). The seigniorage revenue-maximizing point is attained at $\tilde{\pi}^{\max }=1 / \alpha-\hat{y}$, where $\hat{y}$ denotes the growth rate of real income. The left side of equation (6) is the slope of the government's indifference curve, measuring the rate at which the government trades off present government consumption against future damage to the economy. This can be thought of as a quasi-discount rate. It follows from

Figure 1. Inflation and Seigniorage Revenue during Conflict

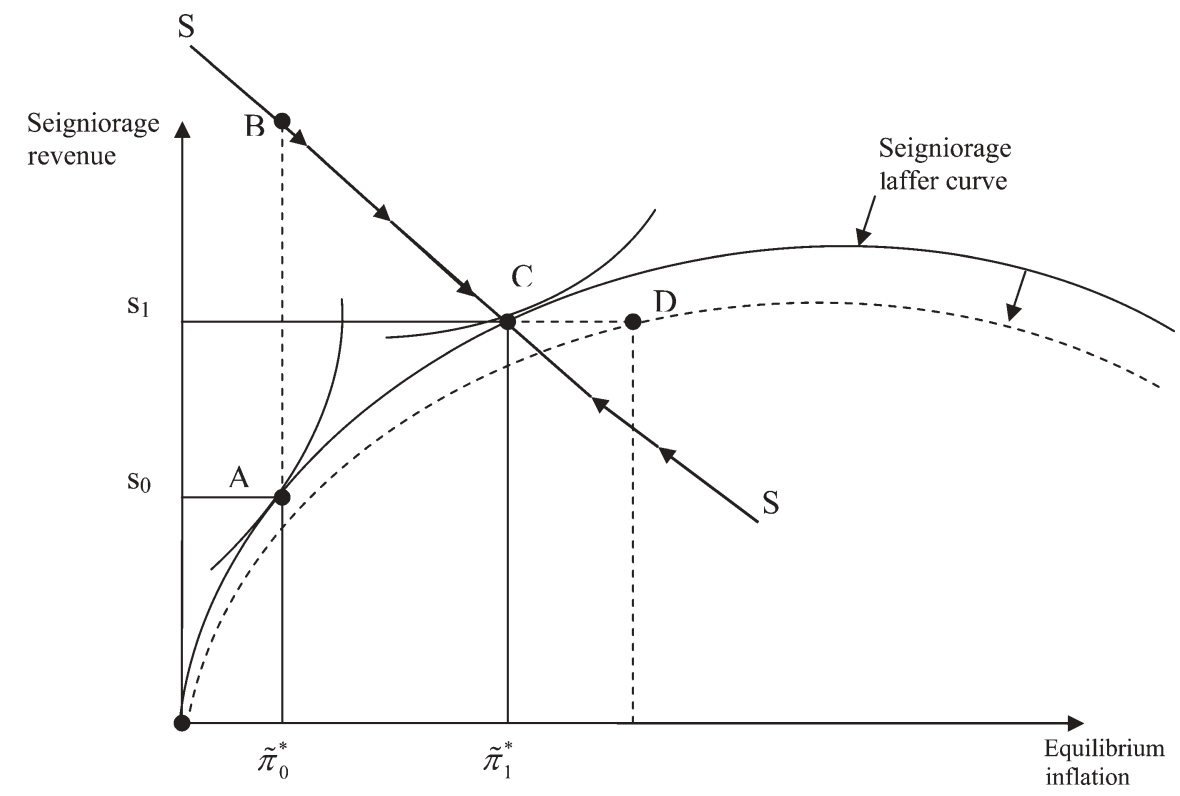


equation (6) that

$$
\frac{\partial \tilde{\pi}_{t}^{*}}{\partial V_{g}}>0 \text { and } \frac{\partial \tilde{\pi}_{t}^{*}}{\partial V_{k}}<0 .
$$

\section{Dynamics}

The short-run dynamics of the model in response to anticipated and unanticipated changes in the fiscal deficit emerge directly from equations (3)-(5). The model assumes that in the short run, $c_{t}$ in equation (4) is constant. Taking the log derivative with respect to time and substituting yields

$$
\frac{d \ln m_{t}}{d t}=\hat{m}_{t}=\hat{y}_{t}-\alpha \dot{\tilde{\pi}}_{t}^{e}
$$

where a hat $\left({ }^{\wedge}\right)$ represents a proportionate change. Using the definition $\hat{M}_{t}=$ $\left(\hat{m}_{t}+\pi_{t}+\hat{y}_{t}\right)$ and denoting the growth in the nominal money supply by $\sigma_{t}=$ $\hat{M}_{t}$ allows inflation to be expressed as

$$
\pi_{t}=\sigma_{t}+\alpha \dot{\tilde{\pi}}_{t}^{e}-\hat{y}_{t}
$$

Substituting equation (9) into equation (5) leads to the following differential equation for inflation expectations:

$$
\dot{\tilde{\pi}}_{t}^{e}=\left(\frac{\beta}{1-\alpha \beta}\right)\left(\sigma_{t}-\pi_{t}^{e}-\hat{y}_{t}\right) .
$$

When inflation expectations adjust sufficiently slowly, such that $\beta<1 / \alpha$, equation (10) is dynamically stable and the economy's adjustment to an increase in the nominal growth of the money supply is denoted by the saddle path SS in figure 1.

\section{Responses During Conflict}

During conflict the government faces increased pressure to spend in order to confront its opponents. At the same time, however-and not necessarily independently_-private sector demand for money declines.

Consider first the government's choice, assuming for the moment no change in the private sector's demand for money. Additional expenditure needs temporarily increase the marginal utility of government consumption, $V_{g}$. This implies an increase in the quasi-discount rate for the duration of the conflict, and, from equation (7), a higher optimal rate of inflation, chosen in order to generate a higher rate of seigniorage. Thus, the government seeks to move along the Laffer curve. It does so by increasing the growth of the money supply, which generates an initial jump in seigniorage to point B. From equation (5), expected inflation 
rises, inducing a decline in real money balances. This continues along SS to the new equilibrium at $\mathrm{C}$, at which point inflation expectations have fully adjusted, such that $\tilde{\pi}_{t}^{e}=\tilde{\pi}_{1}{ }^{*}$. The initial real resource flow at B occurs regardless of how rapidly inflation expectations subsequently adjust, because the increased growth in the money supply is exchanged for real private resources at the price level prevailing in the initial equilibrium. How much additional transitional seigniorage revenue accrues thereafter depends on the private sector's speed of adjustment: the more slowly inflation expectations adjust to the new rate of growth of the money supply, the larger the windfall.

Extracting this higher level of seigniorage assumes, however, no change in the underlying demand for money. For the reasons noted in the introduction, however, this is unlikely. Conflict reduces incomes: it therefore lowers the demand for money and hence seigniorage for any inflation rate. But conflict also induces private agents to disengage from the formal economy and to seek opportunities for capital flight and currency substitution, entailing both an autonomous shift out of domestic currency (a decline in $c_{t}$ in equation (4) and an increase in the inflation semi-elasticity of the demand for money, $\alpha$. These effects on private sector money demand combine to unambiguously shift the Laffer curve downward, so that the level of seigniorage previously feasible at point $\mathrm{C}$ cannot now be achieved at inflation rate $\tilde{\pi}_{1}{ }^{*}$. This level could be generated at a higher rate of inflation, such as that prevailing at $\mathrm{D}$, but clearly the shift inward could be sufficiently large as to render this level of seigniorage infeasible in equilibrium, forcing the government to accept a lower (credible) seigniorage yield. ${ }^{4}$

\section{Learning}

The onset of conflict often comes as a surprise. However, it is reasonable to assume that as conflict endures, the private sector learns about the government's policy rule and adjusts its expectation algorithms accordingly (see, for example, Marcet and Nicolini 2003). Learning algorithms are not explicitly introduced here, but those considered in the literature would be consistent with a gradual increase in $\beta_{t}$ in the face of rising inflation. As learning progresses, inflation expectations adjust more rapidly, the saddle path in figure 1 gets steeper (more so if at the same time the semi-elasticity of money demand increases), and the transitional seigniorage revenue shrinks. Eventually, when $\beta_{t} \geq 1 / \alpha$, the polarity of the saddle path reverses and the economy suddenly experiences an explosive path for inflation expectations. ${ }^{5}$

4. Depending on the precise changes in the demand for money, the seigniorage-maximizing rate of inflation may increase or decrease. As noted earlier, this inflation rate is defined as $\tilde{\pi}^{\max }=(1 / \alpha)-\hat{y}$. Whether it rises or falls during and after conflict depends on the inflation semi-elasticity of money demand, the income elasticity of demand, and the growth of income.

5. Marcet and Nicolini (2003) use adaptive learning algorithms of this class to analyze hyperinflations in Latin America, which tend to follow the same trajectory of periods of high but stable inflation followed by hyperinflationary bursts that are brought under control by aggressive exchange rate-based stabilization. 


\section{Postconflict Responses}

The postconflict period is in some respects a halfway house between peace and war. Although GDP starts to recover, the process takes many years; given the legacy of conflict, money demand is likely to remain below its peacetime level. Moreover, there is evidence that episodes of the loss of fiscal control tend to reduce the post-crisis income elasticity of the demand for money, thereby slowing the remonetization of the economy once inflation pressures have passed and growth has recovered (Adam and Bevan 2004). Similar patterns are likely to be present in the wake of conflict-induced increases in inflation.

While the constraint on raising seigniorage remains tight, government spending needs remain higher than before the war and are indeed likely to increase. Postconflict reconstruction cannot generally be financed by a fiscal peace dividend, because the high risk of conflict reversion typically keeps military spending close to wartime levels (Collier and Hoeffler 2006). Both the persistence of the reduced demand for money and the increased demand for spending imply that the government would choose a higher rate of inflation, such as that entailed by a point in the region of $\mathrm{D}$ on the new Laffer curve in figure 1.

\section{Empirical Analysis}

The empirical analysis uses annual data for a panel of 66 developing economies, 30 of which experienced at least one episode of civil war between 1964 and 2002 (appendix table A-1). Organization for Economic Co-operation and Development countries are excluded, because they are generally free of civil war and tend not to rely on seigniorage to nearly the same extent as other countries. Former communist countries are also excluded, principally because of lack of data. Finally, countries in currency unions are excluded, because union membership constrains their scope for seigniorage. (South Africa is retained, because its dominant role in the Common Monetary Agreement of Southern Africa means that it enjoys de facto full monetary independence.)

Countries with more than 1000 battle-related deaths are classified as being in a state of civil war in that year. ${ }^{6}$ A recent innovation in data on civil war has been the development of measures of conflict intensity based on the extent of combat-related mortality (Lacina and Gleditsch 2005). A priori, it is unclear whether the monetary effects of a conflict will be more closely related to a measure of its intensity (such as combat-related mortality) or to a statedependent measure. The core results reported here are based on a statedependent measure, on the grounds that it better reflects the quantum effects a shift from a state of peace to a state of war may have on expectations relevant for asset demands. (The robustness of the results is tested to alternative measures of conflict; see table A-2.)

6. All war-related data are from the Uppsala Conflict Data Program/International Peace Research Institute Armed Conflict Dataset Version 4-2006 (see Gleditsch and others 2002). 
Four stylized facts characterize the data (table 1). On average, inflation rises during conflict and falls following conflicts, but it remains higher than before the conflict. Seigniorage follows a similar pattern, rising by more than 1 full percentage point of GDP during the conflict (against a preconflict level of 1.8 percent of GDP) before falling back toward, but not quite achieving, its preconflict level. The composition of seigniorage revenue changes markedly. During conflict, governments rely more heavily on seigniorage raised through reserve requirements on the banking system. The differential responses of the (unconstrained) nonbank private sector and the (highly constrained) bank sector are reflected in the summary statistics on real balances. Currency holdings of the nonbank private sector fall from 8.2 percent to 6.2 percent of GDP, while bank reserves rise by almost 3 percentage points of GDP. As a result, the average seigniorage yield on bank reserves rises sharply during conflict. Following a conflict, both revert toward their preconflict values.

\section{Money Demand}

The regression analysis begins with money demand, which constitutes the constraint on government choices. Currency in circulation and reserve holdings by the banking system are distinguished, because reserve holdings may be subject to government control rather than being a choice variable for the private sector. Cagan-style money demand functions of the form

$$
\begin{aligned}
\ln (m)_{i t}= & \gamma_{0}+\gamma_{1} \ln (y)_{i t-1}+\gamma_{2} \ln (\text { pop })_{i t} \\
& +\gamma_{3} \tilde{\pi}_{i t-1}+\gamma_{4} \text { war }_{i t}+\gamma_{5} \text { postwar }_{i t} \\
& +\gamma_{6}\left[\ln (y)_{i t-1} \cdot \text { war }_{i t}\right]+\gamma_{7}\left[\ln (y)_{i t-1} \cdot \text { postwar }_{i t}\right] \\
& +\gamma_{8}\left[\tilde{\pi}_{i t-1} \cdot \text { war }_{i t}\right]+\gamma_{9}\left[\tilde{\pi}_{i t-1} \cdot \text { postwar }_{i t}\right]+\varepsilon_{i t}
\end{aligned}
$$

are estimated (table 2), where countries are denoted by $i$ and time by $t$. The dependent variable, corresponding to each of the measures of money, is defined as a share of GDP. The analysis expands on the specification in equation (4) by

Table 1. Descriptive Statistics (Means)

\begin{tabular}{lcrrr}
\hline Statistic & Full sample (1964-2002) & Prewar & War & Postwar \\
\hline Inflation (percent per year) & 14.3 & 13.3 & 20.4 & 15.3 \\
Reserve money (percent of GDP) & 11.4 & 10.7 & 11.6 & 11.7 \\
Currency & 6.6 & 8.2 & 6.2 & 6.8 \\
Reserves & 4.8 & 2.6 & 5.4 & 4.8 \\
Seigniorage (percent of GDP) & 2.1 & 1.8 & 3.0 & 2.3 \\
Currency & 1.0 & 1.2 & 1.2 & 1.1 \\
Reserves & 1.0 & 0.5 & 1.8 & 1.2 \\
Aggregate GDP growth (percent per year) & 3.6 & 4.4 & 2.6 & 4.5 \\
Per capita GDP growth (percent per year) & 1.2 & 1.9 & 0.4 & 2.3 \\
Aid (percent of GDP) & 6.0 & 4.5 & 4.6 & 6.5 \\
\hline
\end{tabular}

Source: See table A-3. 


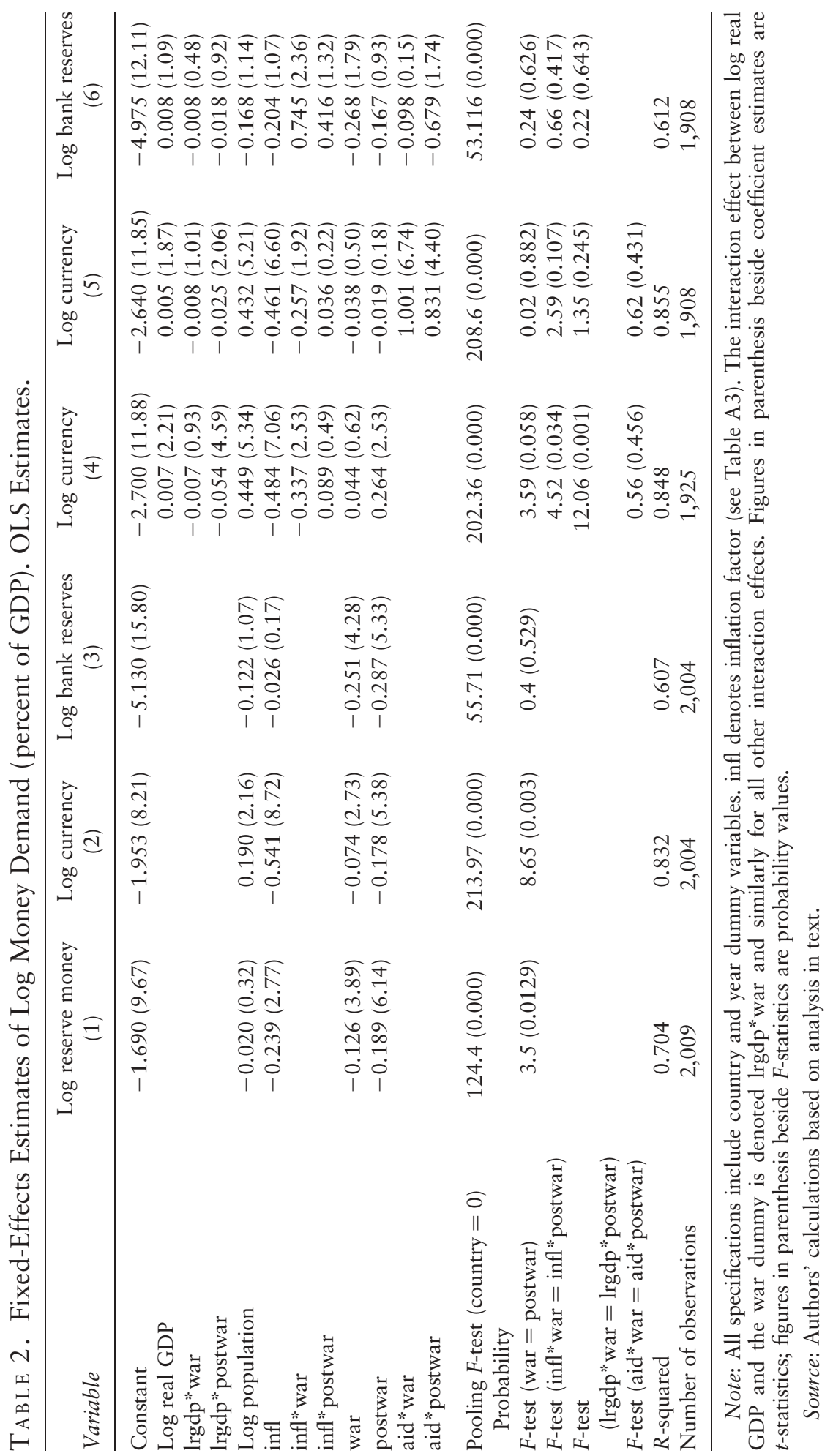


allowing for the possibility that the per capita income elasticity of the demand for money deviates from 1: it thus includes population ( $p \circ p)$ and real income $(y)$ as regressors. To avoid potential problems of endogeneity, $\ln (y)$ enters equation (11) with a lag. Inflation, $\tilde{\pi}$, is as defined in equation (4). The dummy variable war takes the value of 1 if country $i$ is in a state of civil war at time $t$ and 0 otherwise; postwar takes the value of 1 in the first 10 years following the ending of hostilities. The equation residual $\varepsilon_{i t}=\mu_{i}+\omega_{t}+v_{i t}$ is a conventional two-way error component residual. Each equation is estimated using a within-groups/ fixed-effects estimator with a full set of common time and year dummies. Pooling tests reject the null hypothesis of a common intercept. ${ }^{7}$

Controlling for income and inflation, the analysis first introduces civil war and its aftermath as dummy variables (columns 1-3). Both are highly significant and negative for reserve money as a whole and for each of its components. Over and above any effects through income and inflation, conflict reduces the demand for money. More surprisingly, this direct erosion in the demand for money appears to intensify during the postconflict decade, when money demand declines by 19 percent relative to peacetime and 6 percent relative to wartime. The decline relative to wartime is statistically significant, overall and for currency demand.

Bank reserves are not a direct choice variable for the private sector; they are determined by the interaction of government policy on reserve requirements, the banking sector's liquidity preference, and the private sector's demand for inside money. It is, then, not surprising that except for the autonomous war and postwar shift effects, the results for bank reserves are weak: neither income nor inflation is statistically significant, and the overall fit of the equation is markedly lower than for currency demand. What follows therefore concentrates on the demand for currency (the question of how the authorities balance their seigniorage extraction between these two sources is returned to later).

To investigate the transmission paths for this erosion in the private sector's money demand, interaction terms are introduced between both the war and postwar dummy variables and inflation (column 4). Similarly, the possibility that the income elasticity of money systematically differs from unity during and after conflict is allowed for. With the introduction of these interaction terms, the direct effects of both dummies cease to be significant. As suggested by the model in section I, the wartime erosion of currency demand works principally through a heightened sensitivity to inflation: not only does the (absolute) inflation semi-elasticity rise significantly during war, the increase in inflation generates a disproportionate reduction in money demand. Postwar the inflation semi-elasticity of demand is not significantly different from the prewar environment. However, the decline in the income elasticity of money demand, as attested by the postwar interaction term, means that the recovery in postwar

7. Whether behavior differed between the first and second five-year postconflict subperiods was investigated. Because the data do not reject pooling across the subperiods, however, only a single "postwar" effect is reported. 
income does not rebuild money demand proportionally, because the private sector continues to reduce its need for currency per unit of income.

These results are tested for robustness to various measures of the intensity of conflict (the results are reported in appendix table A-2). Columns 1-3 in table A-2, in which conflict is measured directly by the number of combat-related deaths, correspond directly to the same columns in table 2 . The wartime dummy variable is replaced by the number of deaths in each year, and the postwar dummy variable is replaced by the cumulated number of these deaths during the preceding conflict. In columns 4-6 a variant is investigated in which the number of deaths is scaled by population. For both specifications the new variables are significant, the size of the effect on money demand being very close to that found using the dummy variables. Non-nested encompassing tests suggest that from a purely statistical perspective, no measure of conflict dominates. Changing the way in which conflict is measured does not affect the other determinants of money demand, in particular the inflation semi-elasticity, which is the focus here. Column 7 in table A-2 extends the robustness check by interacting the combat death measure of conflict with inflation, with the same results as in table 2, column 4. What follows therefore relies on the results of table 2 , in which conflict is treated as a state variable.

\section{The Government's Choice of Seigniorage}

In raising seigniorage, the government has two instruments at its disposal, the supply of currency and the reserve requirements on the banking system. The supply of currency induces inflation; the reserve requirement is a tax on the banking system, which is liable to reduce the allocative efficiency of finance. The government's chosen level of seigniorage can be expressed as:

$$
s_{i t}=\beta_{0}+\beta_{1} \text { war }_{i t}+\beta_{2} \text { postwar }_{i t}+\lambda_{1} \ln (m)_{i t}+u_{i t},
$$

where $s$ is the seigniorage revenue corresponding to the three measures of money, expressed as percentage points of GDP, and $u_{i t}$ is a two-way error term, as defined above. Substituting for $\ln (m)$ from the money demand equations allows choices to be expressed as determined by the direct and indirect "structural" effects of war and postwar. Collecting the war and postwar terms allows seigniorage outcomes to be expressed as follows:

$$
\begin{aligned}
& s_{i t}=\left(\hat{\beta}_{0}+\hat{\lambda}_{1} \hat{\gamma}_{0}\right)+\hat{\lambda}_{1}\left[\hat{\gamma}_{1} \ln (y)_{i t-1}+\hat{\gamma}_{2} \ln (\text { pop })_{i t}+\hat{\gamma}_{3} \pi_{i t-1}\right] \\
& +\left[\hat{\beta}_{1}+\hat{\lambda}_{1}\left(\hat{\gamma}_{4}+\left(\hat{\gamma}_{1}+\hat{\gamma}_{6}\right) \ln (y)_{i t-1}+\left(\hat{\gamma}_{3}+\hat{\gamma}_{8}\right) \tilde{\pi}_{i t-1}\right)\right] \text { war }_{i t} \\
& +\left[\hat{\beta}_{2}+\hat{\lambda}_{1}\left(\hat{\gamma}_{5}+\left(\hat{\gamma}_{1}+\hat{\gamma}_{7}\right) \ln (y)_{i t-1}+\left(\hat{\gamma}_{3}+\hat{\gamma}_{9}\right) \tilde{\pi}_{i t-1}\right)\right] \text { postwar }_{i t}+w_{i t}
\end{aligned}
$$


where $w_{i t}$ is the composite error term from regressions 11 and 12 . The parameters $\hat{\beta}_{1}$ and $\hat{\beta}_{2}$ reflect the direct "choice" effects; the terms multiplied by $\hat{\lambda}_{1}$ reflect the indirect effects of war and postwar on the demand for money.

Consider the combined seigniorage from currency in circulation and bank reserves. Columns 1-3 in table 3 report the results of the seigniorage regressions. Controlling for the level of real money balances, regressions introduce dummy variables for the war and postwar periods. Both are highly significant: wartime and postwar governments resort more to seigniorage than peacetime governments do. The coefficients on the two dummies are not significantly different from each other: postwar governments are as desperate for revenue as wartime governments. Conditional on the level of the constraint, war conditions increase seigniorage extraction by about 1.1 percent of GDP. Given that prewar seigniorage is about 1.8 percent of GDP (see table 1), this is a substantial increase in needs. In the postconflict decade the direct effect is virtually as large as during the war, at 0.8 percent of GDP. This is consistent with the observed continuing high levels of government military spending in postconflict conditions.

While the total direct effects of wartime and postwar conditions on the government's resort to seigniorage are the same, their composition differs. During war governments rely predominantly on taxing the banking system, with four-fifths of total seigniorage generated from this source. Postwar, although taxation of the banking system still dominates, there is some shift toward greater reliance on printing currency. This shift may be appropriate: because of the collapse of investment, allocative financial efficiency may temporarily be unimportant during conflict.

War and postwar conditions alter seigniorage not only through direct effects on government choices but also through their effects on income and money demand. While government needs increase pressure to resort to seigniorage, the tightening of the constraint resulting from lower income and the erosion in the demand for money reduces the amount of seigniorage that can be raised. The direct effect combined with the two offsetting indirect effects determines the overall effect of war and its aftermath on seigniorage. The decline in overall seigniorage between war and postwar noted in table 1 reflects both a decline in needs, of about 0.3 percentage points of GDP on average, and a reduction in the seigniorage tax base of about the same amount (table 4).

\section{Postconflict Assistance}

During the postwar period, the government is faced with a harsh tradeoff. The need for revenue increases, but the capacity to raise it through seigniorage deteriorates, as the demand for money erodes. From the long-run perspective there is a case for reducing resort to seigniorage, thereby investing in the reconstruction of money demand and so restoring the future potential for sustainable seigniorage. From the short-run perspective there is a case for further resort to seigniorage, despite its rising cost in terms of inflation and damage to the banking system. Does aid resolve this dilemma? 


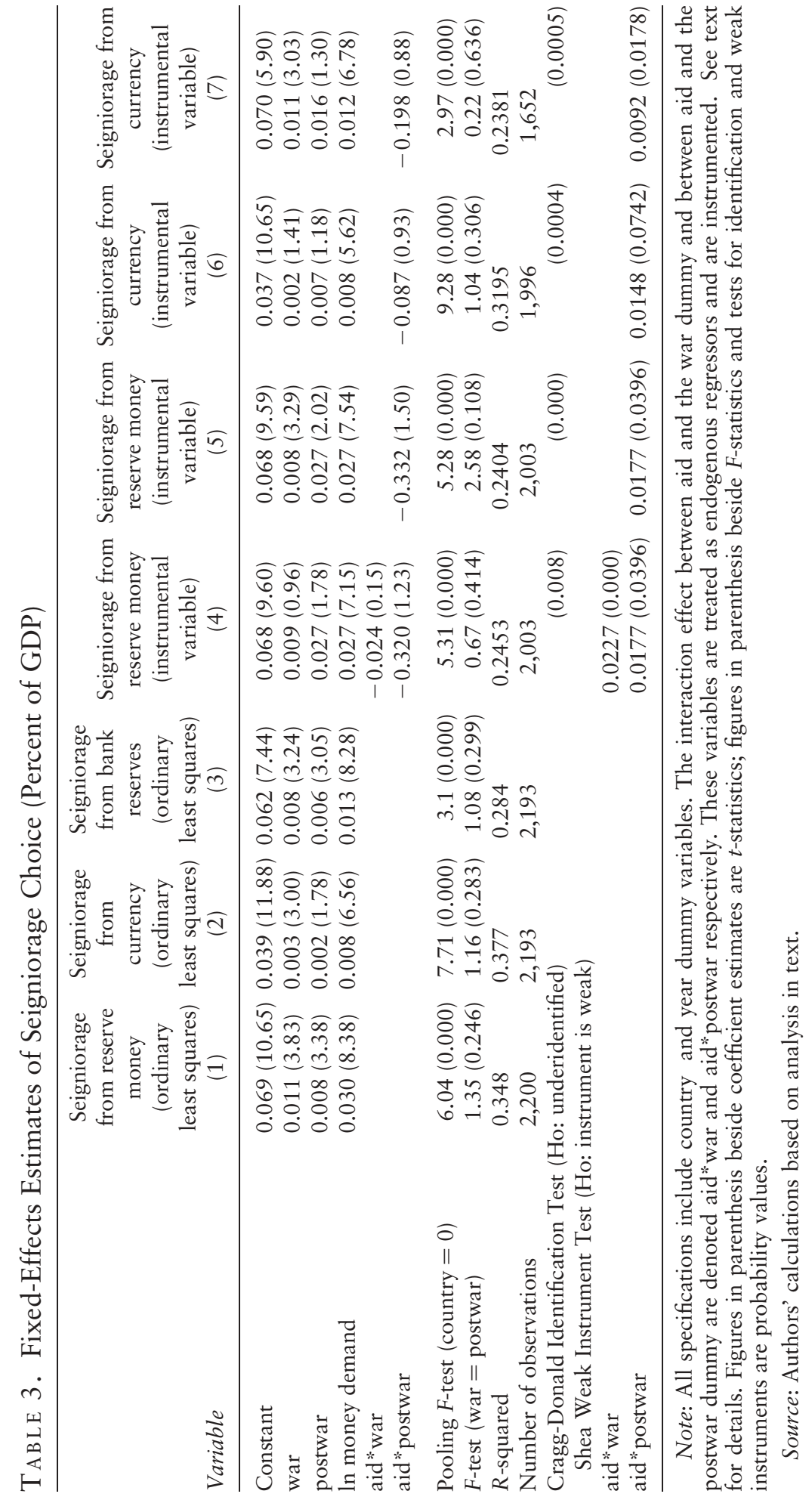


Table 4. Decomposition of War and Postwar Seigniorage Yields (Percent of GDP)

\begin{tabular}{lcrr}
\hline Period/cause of change in seigniorage & Reserve money & Currency & Bank reserves \\
\hline War & & & \\
Direct needs & 1.10 & 0.30 & 0.80 \\
Constraint shift & -0.34 & -0.06 & -0.33 \\
$\quad$ Net seigniorage & 0.76 & 0.24 & 0.47 \\
Postwar & 0.80 & 0.20 & 0.60 \\
Direct needs & -0.59 & -0.14 & -0.37 \\
Constraint shift & 0.21 & 0.06 & 0.23 \\
Net seigniorage & 1.80 & 1.20 & 0.50 \\
Mean prewar seigniorage & & & \\
\hline
\end{tabular}

Source: Authors' calculations based on analysis in text.

Postconflict reconstruction is the original rational for aid. Indeed, the original name for the World Bank was the International Bank for Reconstruction; the words "and Development" were added as an afterthought. Following the end of conflict, there is typically a surge in aid, as donors respond to perceived postconflict needs. Aid has indeed been found to be significantly more effective in enhancing growth during the postconflict decade than at other times (Collier and Hoeffler 2004a). Postwar aid can also have monetary effects, which can affect the government's need for seigniorage.

\section{Aid and the Government Choice of Seigniorage}

Aid, expressed as a share of GDP, is introduced into the seigniorage regression as follows:

$$
\begin{aligned}
s_{i t} & =\beta_{0}+\beta_{1} w_{a r}+\beta_{2} \text { postwar }_{i t}+\beta_{3}\left[\text { aid }_{i t} \cdot \text { war }_{i t}\right]+\beta_{4}\left[\text { aid }_{i t} \cdot \text { postwar }_{i t}\right] \\
& +\lambda_{1} \ln (m)_{i t}+u_{i t}
\end{aligned}
$$

The supply of aid cannot be assumed to be exogenous to government fiscal choices: donors might plausibly either increase aid flows in response to fiscal desperation or reduce them in response to fiscal irresponsibility. Aid is therefore instrumented using a vector of political, cultural, and economic measures of distance between each recipient country and its principal Development Assistance Committee aid donors (see Tavares 2003). ${ }^{8}$ The underlying idea is that to some extent, bilateral donor governments provide aid based on historical ties and

8. The aid instrument is defined as $\tilde{a}_{i t}=\sum_{j} \boldsymbol{\theta}_{\mathrm{ij}} A_{\mathrm{ji}}$, where $\tilde{a}_{\mathrm{it}}$ denotes instrumented aid for recipient $\mathrm{i}$ in period $t ; \mathbf{\theta}_{\mathrm{ij}}=\left(1 / D_{\mathrm{ij}}, L_{\mathrm{ij}}, R_{\mathrm{ij}}\right)$ is a vector of time-invariant measures of "distance" between donor $\mathrm{j}$ and recipient $\mathrm{i}$, where $D_{\mathrm{ij}}$ is the distance between the capital cities of $\mathrm{i}$ and $\mathrm{j} ; L_{\mathrm{ij}}$ is a dummy variable taking the value of 1 when $\mathrm{i}$ and $\mathrm{j}$ share the same official language and 0 otherwise; $R_{\mathrm{ij}}$ is a dummy variable taking the value of 1 when $i$ and $j$ share the same dominant religion and 0 otherwise; and $A_{j t}$ is donor i's aid to GNI ratio in time $t$. This measure is calculated for the five principal aid donors: the United States, the United Kingdom, Japan, France, and Germany. 
domestic budgetary circumstances that are unrelated to circumstances in the recipient country. As the instrument validity tests reported at the bottom of table 3 suggest, the instrumenting strategy adopted here appears reasonably robust.

Columns 4 and 5 in table 3 introduce aid instrumented in this way into the seigniorage regression for reserve money. During wartime aid is unsurprisingly negligible; instrumented aid is therefore insignificant when interacted with the wartime dummy variable. In effect, the aversion of donors to funding warfare overrides the proclivities of bilateral donors to provide aid. When the interaction of aid with this wartime dummy variable is dropped, the interaction between aid and the postwar dummy variable is negative and substantial. Although it is only on the borderline of significance, it is fully consistent with theory: it is not surprising that aid reduces the resort by government to seigniorage. An increase in aid equivalent to 1 percentage point of GDP reduces seigniorage by about 0.33 percentage points of GDP.

Because aid usually surges following the end of conflict, the addition of aid makes a substantial difference to the other components of the regression. In particular, the direct effect of the postwar dummy variable is now about four times its previous value. Although the regression involves a small reduction in the sample, this is not the explanation for the change. ${ }^{9}$ Thus, controlling for aid, postwar governments appear to be far more desperate for revenue even than they are during war. The surge in aid postwar accommodates these needs and thereby reduces resort to seigniorage.

Columns 6 and 7 in table 3 again show how the resort to seigniorage is split between currency and bank reserves, in this case controlling for post-conflict aid. Although the differences between seigniorage extracted from currency and from bank reserves seen in columns 2 and 3 remain, there is no statistically significant difference in the impact of post-conflict aid.

\section{Aid and Money Demand}

Because aid reduces the resort to seigniorage, it reduces inflation. Indirectly, aid therefore raises the demand for money. Aid also significantly augments growth in the postwar context (Collier and Hoeffler 2004a), which directly raises the demand for money. The theoretical specification of the demand function suggests that conditional on income and inflation, aid should have no direct effect on private sector demand for money. However, in the context of the aftermath of civil war, there may be such an effect. One likely explanation for the severe erosion of the demand for money in the postwar period is a "peso effect," in which the high risk of a reversion to conflict supports expectations of further inflation in excess of that directly implied by current experience. Conceivably, large aid programs might help reassure citizen, thereby directly increasing the demand for money. This hypothesis is tested, by modifying the

9. Reestimating the regression in column 1 on the reduced sample does not significantly affect the coefficient estimates. 
demand for money function as follows:

$$
\begin{aligned}
\ln (m)_{i t}= & \gamma_{0}+\gamma_{1} \ln (y)_{i t-1}+\gamma_{2} \ln (\text { pop })_{i t}+\gamma_{3} \tilde{\pi}_{i t-1} \\
& +\gamma_{4} \text { war }_{i t}+\gamma_{5} \text { postwar }_{i t} \\
& +\gamma_{6}\left[\ln (y)_{i t-1} \cdot \text { war }_{i t}\right]+\gamma_{7}\left[\ln (y)_{i t-1} \cdot \text { postwar }_{i t}\right] \\
& +\gamma_{8}\left[\tilde{\pi}_{i t-1} \cdot \text { war }_{i t}\right]+\gamma_{9}\left[\tilde{\pi}_{i t-1} \cdot \text { postwar }_{i t}\right] \\
& +\gamma_{10}\left[\text { aid }_{i t} \cdot \text { war }_{i t}\right]+\gamma_{11}\left[\text { aid }_{i t} \cdot \text { postwar }_{i t}\right]+\varepsilon_{i t} .
\end{aligned}
$$

In a reduced-form regression of the type estimated here, any impact of aid inflows must reflect a direct effect, because the regression controls for the indirect effects.

It is reasonable to assume that aid is weakly exogenous with respect to private sector demand for money; aid is therefore introduced into the demand for money functions using ordinary least squares (table 2, columns 5 and 6). Aid has a small and statistically insignificant effect on the demand for reserve money (not shown in table 2), but this is because it has strong but offsetting effects on the two components of money. Aid significantly increases the demand for currency in circulation both during war and in the postconflict period (column 5); it also reduces the demand for bank reserves by the same order of magnitude (column 6). The "demand" for bank reserves in the context of civil war and its aftermath is most reasonably interpreted as being a coerced demand: banks must comply with central bank regulations. Hence, the decline in "demand" as a result of postwar aid is likely to reflect the reduced pressure for government revenue. These aid effects are not large, but they are significant: as the regression controls for both income and inflation, the result is consistent with the hypothesis that aid reassures and so reduces the "peso problem" arising from fears of collapse.

The inclusion of aid in the money demand regression changes the direct effect of the postwar dummy variable quite substantially. In the analysis of section II, which omitted aid, it appeared that the demand for money eroded considerably more during the postwar period than during the war itself. Controlling for aid, this is no longer the case. The "pure" effect of the postwar period on money demand continues to be substantially adverse in comparison to the prewar peace, but it is now significantly and substantially better than during the war itself.

Postwar aid "reconstructs" the demand for money and hence seigniorage capacity through three distinct routes. First, postconflict aid directly substitutes for seigniorage revenue, enabling the government to reduce its reliance on inflationary finance and thereby stimulating recovery in the demand for money. Second, postconflict aid restores money demand indirectly, through its effect on income growth. While the overall effect of aid on growth is controversial, there is evidence that it is particularly effective in postwar situations (Collier and Hoeffler 
2004a). Finally, as the regression results suggest, aid also appears to play a role in supporting a modest portfolio shift in favor of domestic money demand.

\section{Applications to Postconflict Monetary Reconstruction}

The regression results are applied to two pertinent questions concerning postconflict aid. The first concerns the marginal effects of postconflict aid; the second concerns the paths of reconstruction of the monetary base postconflict, with and without aid.

The analysis draws on the evidence from the seigniorage and money demand regressions, combined with evidence from Collier and Hoeffler (2004a), to simulate the marginal impact on inflation and money demand of an increase in postconflict aid. Given the peculiar nature of the demand for bank reserves, the focus here is exclusively on currency demand. Using the sample estimates for the levels of inflation and money demand at the start of the postconflict period, the analysis measures the marginal impact of an increase in aid of 1 percentage point of GDP, sustained over a 10-year period. The impact consists of two distinct components. The first is the change in inflation arising from the aid-induced fall in seigniorage needs, which determines the end-of-conflict demand for currency (this represents a movement along the immediate postconflict Laffer curve). The second is the improvement in postconflict currency demand, including the induced effect of the further fall in inflation associated with rising currency demand given the marginal change in seigniorage needs. The results (table 5) suggest that if the fall in desired seigniorage noted in table 3 were sustained over the 10 -year postwar period, the aid inflow would lead to a substantial restoration in real money balances of about 2.9 percentage points of GDP (an increase of almost 50 percent over the end-of-conflict level) and an almost halving of inflation, from about 20 percent to just over10 percent a year (table 5).

The regression results are also used to track the evolution of the monetary base, inflation and seigniorage for the typical conflict-affected country under two scenarios: no aid and aid at the level typical of postconflict situations. Each dynamic simulation is computed as a recursive forecast (figures 2-4). Exploiting the adaptive inflation expectations specification used in the estimations, and given exogenous paths for real income growth (from tables 1 and $5)$, the demand for currency at time $t$ is predetermined, given the relevant coefficient values from table 3 . With currency demand predetermined, changes in seigniorage needs from table 2 then imply changes in inflation and the current seigniorage yield. The change in inflation is used to update the demand for money in $t+1$ and so forth. The coefficients on the war and postconflict dummy variables are derived from a cross-section of observations; they therefore only approximate a genuinely dynamic analysis. In particular, they produce discrete jumps upon the onset and end of war that exaggerate the likely actual speed of adjustment. These artificial jumps are juxtaposed against more genuinely dynamic adjustments to inflation and income. 
TABLE 5. Marginal Impact of 1 Percent Increase in Aid Sustained Over 10-Year Period

\begin{tabular}{|c|c|c|c|c|}
\hline \multirow[b]{2}{*}{ Channel } & \multirow[b]{2}{*}{ Impact } & \multicolumn{3}{|c|}{ Impact on: } \\
\hline & & $\begin{array}{c}\text { Seigniorage } \\
\text { (percent } \\
\text { of GDP) }\end{array}$ & $\begin{array}{l}\text { Inflation } \\
\text { (percent } \\
\text { per year) }\end{array}$ & $\begin{array}{l}\text { Money } \\
\text { demand } \\
\text { (percent } \\
\text { of GDP) }\end{array}$ \\
\hline \multicolumn{5}{|l|}{ Inflation effect } \\
\hline $\begin{array}{l}\text { Impact of aid on aggregate seigniorage } \\
\text { needs }^{\mathrm{a}}\end{array}$ & -0.33 & & & \\
\hline Decline in seigniorage from currency ${ }^{\mathrm{b}}$ & & -0.12 & & \\
\hline Initial postconflict currency balances ${ }^{c}$ & 6.20 & & & \\
\hline Inflation $(\text { factor })^{c}$ & 0.20 & & & \\
\hline Inflation semi-elasticity ${ }^{\mathrm{d}}$ & -0.72 & & & \\
\hline Change in annual inflation & & & -3.08 & \\
\hline Induced increase in currency demand & & & & 0.10 \\
\hline \multicolumn{5}{|l|}{ Income effect } \\
\hline $\begin{array}{l}\text { Impact of aid on postconflict growth } \\
\text { (percent per year) }^{\mathrm{e}}\end{array}$ & 0.26 & & & \\
\hline $\begin{array}{l}\text { Postwar income elasticity of currency } \\
\text { demand }^{\text {d }}\end{array}$ & 0.98 & & & \\
\hline Increase in currency demand & 0.26 & & & 2.56 \\
\hline $\begin{array}{l}\text { Postwar inflation semi-elasticity of } \\
\text { currency demand }^{\text {d }}\end{array}$ & -0.43 & & & \\
\hline Change in annual inflation) & -0.88 & & & \\
\hline $\begin{array}{l}\text { Change in inflation over } 10 \text {-year post war } \\
\text { period }\end{array}$ & & & -677 & \\
\hline Induced increase in currency demand & & & & 0.14 \\
\hline \multicolumn{5}{|l|}{ Portfolio effect } \\
\hline Portfolio shift coefficient ${ }^{\mathrm{d}}$ & 0.83 & & & \\
\hline $\begin{array}{l}\text { Currency balances, including Inflation } \\
\text { effect }^{\mathrm{f}}\end{array}$ & 6.30 & & & \\
\hline Increase in currency demand & & & & 0.05 \\
\hline $\begin{array}{l}\text { Change in inflation over } 10 \text {-year post war } \\
\text { period }\end{array}$ & & & -0.18 & \\
\hline Induced increase in currency demand & & & & 0.00 \\
\hline \multicolumn{5}{|l|}{ Total effects } \\
\hline $\begin{array}{l}\text { Total direct reduction in seigniorage } \\
\text { requirements }\end{array}$ & & -0.12 & & \\
\hline Total postwar increase in money demand & & & & 2.86 \\
\hline Total postwar reduction in inflation & & & -10.04 & \\
\hline
\end{tabular}

${ }^{\mathrm{a}}$ Table 3, column 5 .

${ }^{\mathrm{b}}$ Assumes that 36 percent of seigniorage revenue is to be raised from currency in circulation.

${ }^{\mathrm{c}}$ Table 1

${ }^{\mathrm{d}}$ Table 2, column 5 .

${ }^{\mathrm{e}}$ From Collier and Hoeffler (2004a)

${ }^{\mathrm{f}}$ Includes increase in currency demand due to initial postconflict inflation reduction.

Source: Authors' calculations based on analysis in text. 
Figure 2. Impact of Postconflict Aid on Inflation (percent per year)

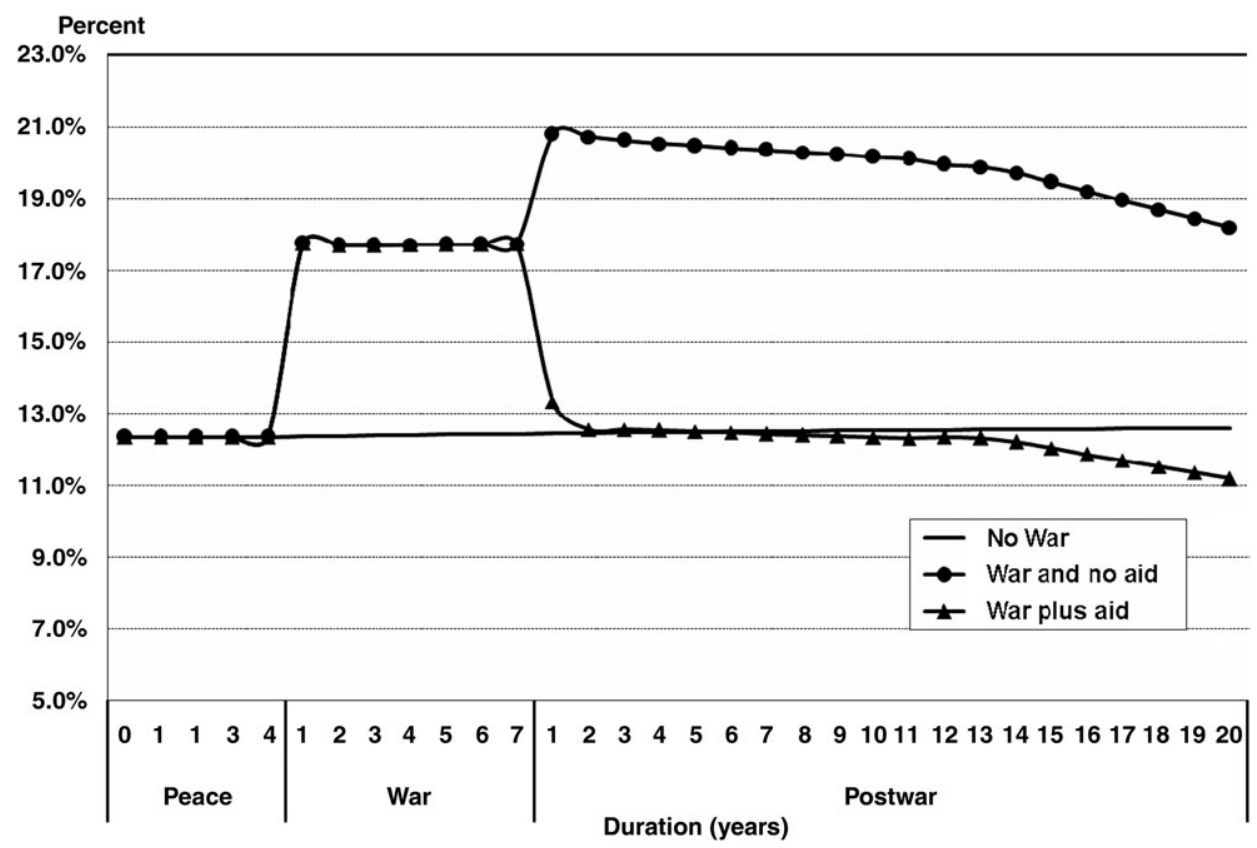

Figure 3. Impact of Postconflict Aid on Currency Demand (percent of GDP)

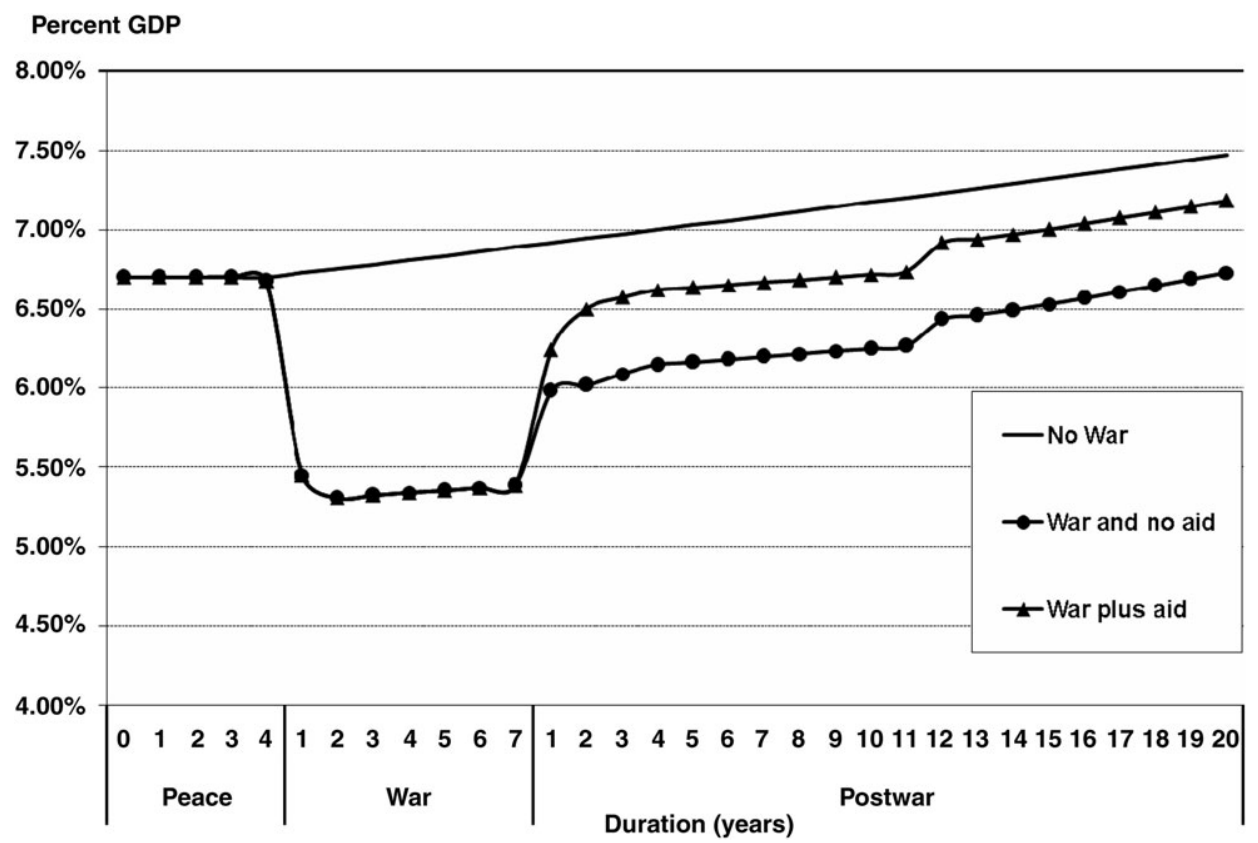


Figure 2 plots the rate of inflation. The typical country in the sample had a preconflict rate of inflation of about 12 percent. During war this rate rises to about 18 percent, although not as abruptly as depicted in the figure. In the absence of aid the regressions reported in tables 2 (column 5) and 3 (column 6) imply that there would be a substantial increase in inflation to 21 percent with the onset of peace, an adjustment that is likely to be more gradual than depicted. This increase reflects the heavy fiscal needs facing postconflict governments. Postconflict aid at typical levels is sufficient not only to meet these needs but to enable the government to invest in monetary reconstruction. The inflation rate with aid rapidly reverts to its peacetime level and indeed starts to dip below it, as is necessary to rebuild money demand. As postconflict aid typically surges immediately after the end of conflict, this fiscally driven effect may well be rapid.

Figure 3 plots the consequences for the demand for currency as a share of GDP. During war currency demand collapses from about 6.7 percent to about 5.3 percent of GDP. In the absence of aid currency demand nevertheless rebounds somewhat following the end of the conflict, to about 6 percentage points of GDP, but thereafter it stalls near this level: money demand is never rebuilt to its preconflict level. The rebound followed by stall is likely to be a spurious artifact of the postconflict dummy variable; the fact that the ceiling to the recovery is well short of the preconflict level is not. With aid the initial postconflict rebound is a little higher, at about 6.5 percent of GDP; the key difference is that thereafter it gradually recovers toward its peacetime level. Even after a decade, recovery is not complete, but it is substantially accomplished.

Figure 4. Impact of Postconflict Aid on Seigniorage (percent of GDP)

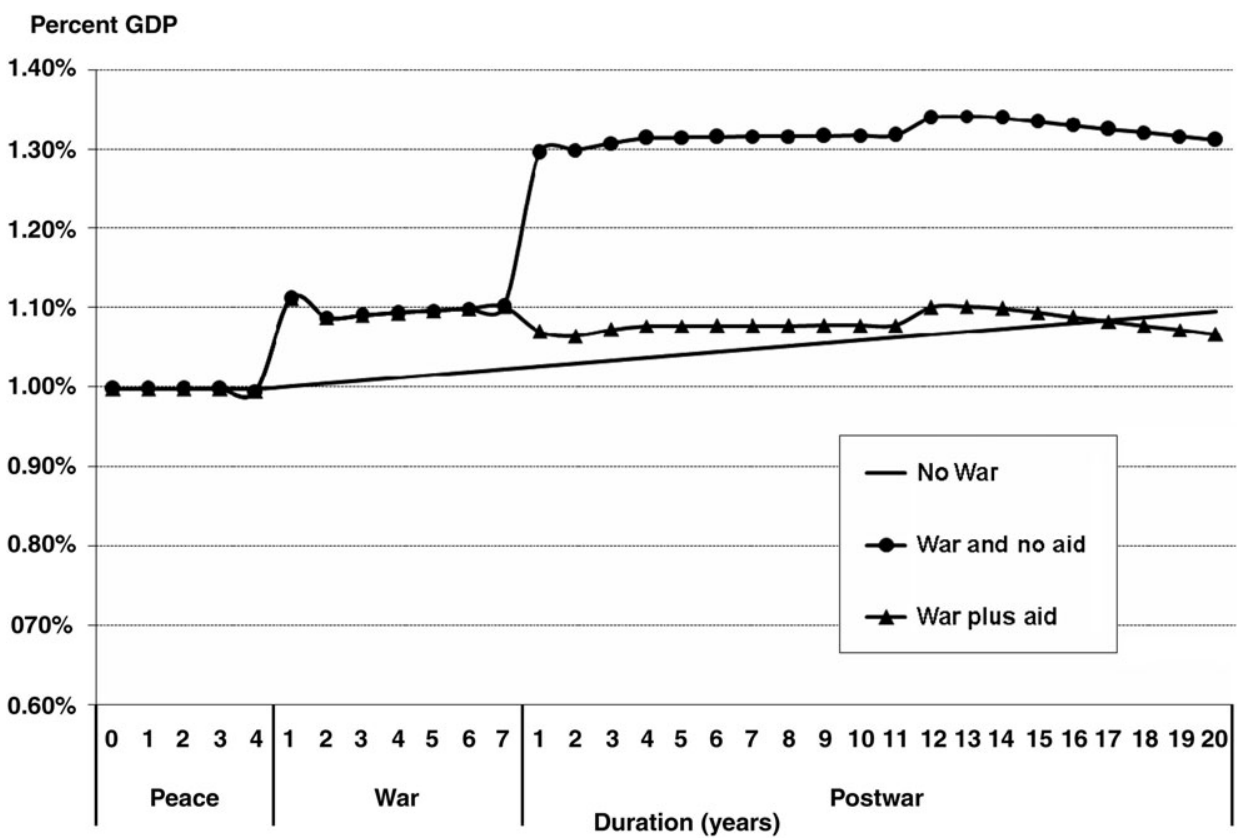


Figure 4 tracks seigniorage from currency as a percent of GDP. Such seigniorage increases during the war; if postconflict aid is not forthcoming, a dramatic exploitation of the currency occurs with the onset of peace. While the speed of the increase is surely exaggerated by the dummy variable, the onset of increased fiscal needs is indeed liable to be rapid. Aid enables the government not only to avoid this jump in seigniorage but gradually to bring its taxation of the currency down to its peacetime level. The process of reversion is slow, taking almost 20 years.

\section{CONCLUSION}

Postconflict situations are characterized by an unusually wide range of outcomes. While on average economies rebound from wartime decline, decline continues in some countries, and about 40 percent of countries revert to conflict within a decade. Policy choices concerning the economic recovery of these hopeful but fragile situations have received far less attention than issues of political design and humanitarian needs.

Seigniorage is strategic, both because as revenue of last resort it reveals government preferences and because the ability to raise it reflects the degree of confidence of private actors in a fundamental government commitment. The results imply a rationale for aid that is peculiar to the postconflict macroeconomic situation. In effect, just as infrastructure needs to be reconstructed, so too does the demand for money. Even controlling for inflation and income, private demand for money erodes sharply in the postwar period. Yet in the absence of aid, postconflict governments resort to seigniorage far more heavily after war than during it.

While the restoration of the demand for money is beyond the capacity of the typical postconflict government to finance out of its own resources, it is both an important objective in itself and a useful indicator of the broader restoration of confidence. Aid is effective in reconstructing the long-term scope for seigniorage, acting through three distinct routes. The most obvious one is that for which aid is primarily intended: it raises the growth of income, thereby raising the demand for money. Unfortunately, this effect is relatively weak in postwar conditions, because the income elasticity of the demand for money is lower than in normal times. However, two other effects occur. First, aid reduces the need for the government to resort to seigniorage and so reduces inflation. Second, and more surprisingly, over and above the effects through income and inflation, postwar aid has a direct effect, perhaps through strengthening confidence in the maintenance of peace. This article treats aid as a single aggregate, abstracting from different types and uses. The core result, however, implies that it is aid to the budget that achieves monetary reconstruction. This need not necessarily imply the superiority of budget support. Because much project aid is likely to be fungible, it indirectly relieves the budget, even though it is ostensibly earmarked. 
Postconflict aid is decisive in achieving monetary reconstruction. Rather than deteriorating, inflation and seigniorage-the monetary variables under the control of the government-revert to peacetime levels. The demand for currency, which is the constraint on government choices, takes longer to recover, because civil war severely damages confidence in the currency. Aid helps facilitate a gradual recovery. These monetary effects of postconflict aid have been an unsung success: attention has focused on the more televisual roles of aid in humanitarian relief and the reconstruction of physical infrastructure. The effects on monetary reconstruction are no less real or substantial.

APPENDIX

Table A-1. Civil War Episodes in Sample Countries

\begin{tabular}{ll}
\hline Country & $1991-$ present \\
\hline Algeria & $1973-77$ \\
Argentina & $1985-92$ \\
Bangladesh & $1995-$ present \\
Burundi & $1978-$ present \\
Colombia & $1967,1969-70$ \\
Egypt, Arab Republic of & $1979-91$ \\
El Salvador & $1966-91$ 2002-present \\
Ethiopia & $1966-95$ \\
Guatemala & $1985-$ present \\
India & $1975-92,1997-$ present \\
Indonesia & $1966-68,1979-88,1990-93,1996-97,1999-2001$ \\
Iran & $1964-$ present \\
Israel & $1975-91$ \\
Lebanon & $1975-89$ \\
Morocco & $1999-$ present \\
Nepal & $1978-79,1981-89$ \\
Nicaragua & $1966-70$ \\
Nigeria & $1971,1974-77$ \\
Pakistan & $1980-99$ \\
Peru & $1970-$ present \\
Philippines & $1991-94,1997-2002$ \\
Rwanda & $1992-2000$ \\
Sierra Leone & $1975-88$ \\
South Africa & $1971,1983-2001$ \\
Sri Lanka & $1963-72,1983-$ present \\
Sudan & $1979-82$ \\
Syria & $1974-82$ \\
Thailand & $1978-79,1981-91,1994-$ present \\
Uganda & $1974-79$ \\
Zimbabwe &
\end{tabular}

Source: Gleditsch and others 2002.

Note: Nonconflict countries in the sample include Bahrain, Barbados, Belize, Bhutan, Bolivia, Botswana, Brazil, Cape Verde, Chile, Costa Rica, Ecuador, Fiji, The Gambia, Ghana, Haiti, Honduras, Jamaica, Jordan, Kenya, Kuwait, Madagascar, Malawi, Mauritius, Oman, Paraguay, Saudi Arabia, the Seychelles, the Solomon Islands, Suriname, Tonga, Trinidad and Tobago, Tunisia, Uruguay, Vanuatu, Républica Bolivariana de Venezuela, and Zambia. 


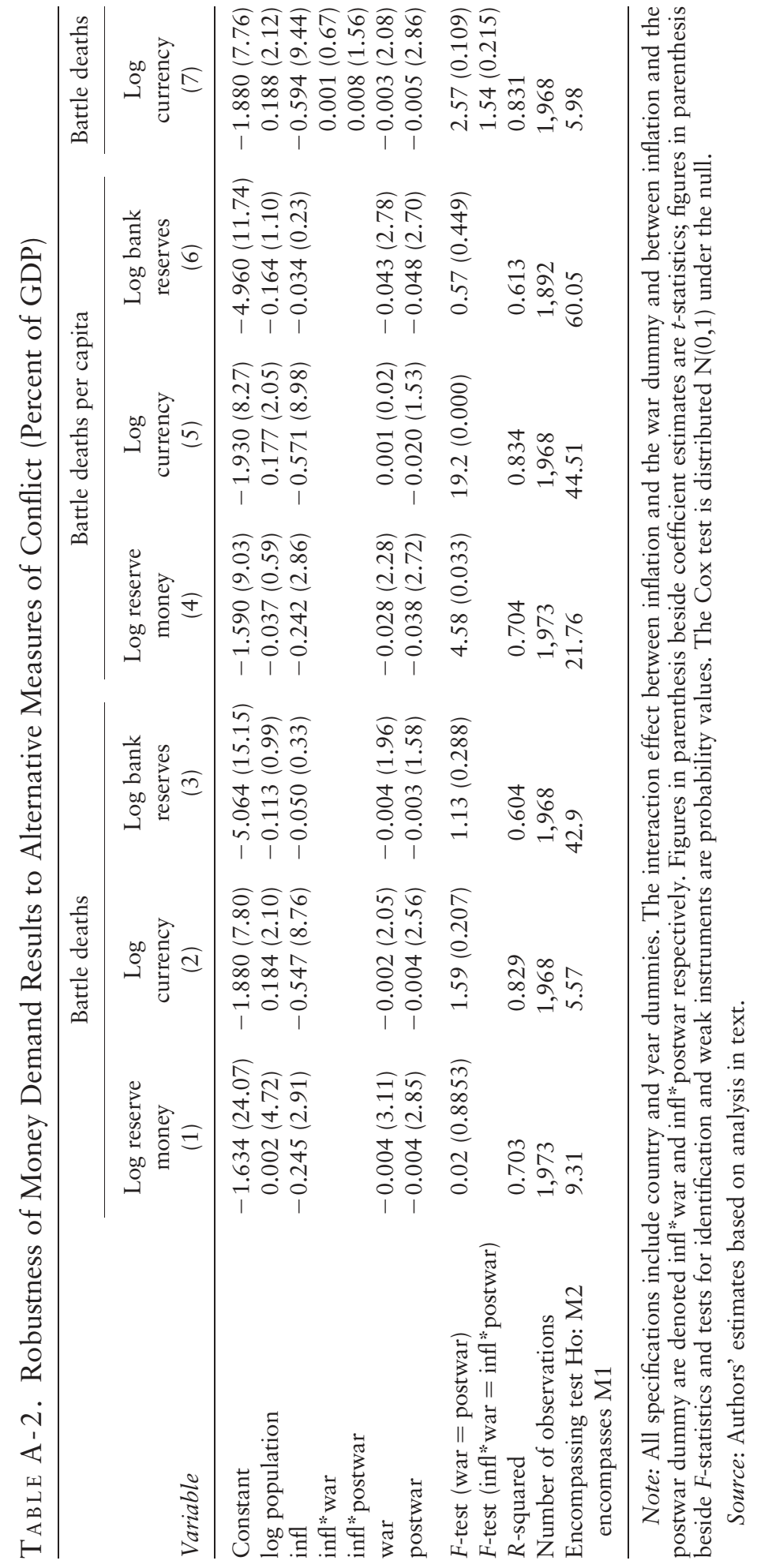




\section{TAble A-3. Variable Definitions and Data Sources}

\begin{tabular}{|c|c|c|}
\hline Variable & Meaning & Definition and source \\
\hline$m$ & $\begin{array}{l}\text { Money aggregate } \\
\text { (percent of GDP) }\end{array}$ & $\begin{array}{l}\text { Defined for reserve money (IMF } 2006 \text { line 14) and its } \\
\text { components, currency in circulation (IMF } 2006 \text { line 14a) and } \\
\text { bank reserves (IMF } 2006 \text { line 20), all measured as share of } \\
\text { current price GDP in local currency (World Bank 2006) }\end{array}$ \\
\hline$s$ & $\begin{array}{l}\text { Seigniorage } \\
\text { (percent of GDP) }\end{array}$ & $\begin{array}{l}\text { Defined for each money aggregate as } s_{t}=\left(M_{t}-M_{t-1}\right) / \\
\left((1 / 2)\left(Y_{t}+Y_{t+1}\right)\right) \text { for nominal money aggregate, } M \text {, and } \\
\text { nominal GDP, } Y \text {. }\end{array}$ \\
\hline$y$ & Real GDP & Constant price GDP (World Bank 2006) \\
\hline рор & Population (millions) & World Bank (2006) \\
\hline$\tilde{\pi}$ & Inflation factor & $\begin{array}{l}\text { Defined as } \tilde{\pi}=\pi /(1+\pi) \text {, where } \pi \text { denotes annual change in } \\
\text { consumer price index (World Bank 2006) }\end{array}$ \\
\hline war & Civil war indicator & See text for explanation (Gleditsch and others 2002) \\
\hline postwar & Postwar indicator & See text for explanation (Gleditsch and others 2002) \\
\hline aid & Aid (percent of GDP) & $\begin{array}{l}\text { Net official development assistance (excluding technical } \\
\text { assistance) as percent of GDP (World Bank 2006) }\end{array}$ \\
\hline
\end{tabular}

Source: Authors' compilation.

\section{REFERENCES}

Adam, Christopher. 1995. "Fiscal Adjustment, Financial Liberalization and the Dynamics of Inflation: Some Evidence from Zambia." World Development 23(5):735-50.

Adam, Christopher, and David Bevan. 2004. "Fiscal Policy Design in Low-Income Countries." In Tony Addison and Alan Roe eds., Fiscal Policy for Development: Poverty, Reconstruction and Growth. London: Palgrave Macmillan.

Bruno, Michael, and Stanley Fischer. 1990. "Seigniorage, Operating Rules and the High Inflation Trap.” Quarterly Journal of Economics 105(2):353-74.

Cagan, Philip. 1956. "The Monetary Dynamics of Hyperinflation." In Milton Friedman, ed., Studies in the Quantity Theory of Money. Chicago: University of Chicago Press.

Calvo, Guillermo, and Leonardo Leiderman. 1992. "Optimal Inflation Tax under Pre-Commitment: Theory and Evidence.” American Economic Review 82(1):179-94.

Cashin, Paul, Nadeem Ul Haque, and Nils Olekalns. 2002. "Tax Smoothing, Tax Tilting and Fiscal Sustainability in Pakistan." Economic Modelling 20(1):47-67.

Collier, Paul. 1999. "On the Economic Consequences of Civil War." Oxford Economic Papers 51(1):168-83.

Collier, Paul, and Anke Hoeffler. 2004a. "Aid, Policy and Growth in Post-Conflict Societies." European Economic Review 48(4):1125-45.

Collier, Paul, and Hoeffler Anke. 2004b. "Greed and Grievance in Civil War." Oxford Economic Papers 56(4):563-95.

—. 2006. "Military Spending in Post-Conflict Societies." Economics of Governance 7(1):89-107.

- 2007. "Unintended Consequences: Does Aid Finance Military Spending?" Oxford Bulletin of Economics and Statistics 69(1):1-27.

Gleditsch, Nils Petter, Peter Wallensteen, Mikael Eriksson, Margareta Sollenburg, and Havard Strand. 2002. “Armed Conflict 1956-2001: A New Data Set.” Journal of Peace Research 39(5):615-37.

IMF (International Monetary Fund). 2006. International Financial Statistics. Washington, D.C. 
Lacina, Bethany, and Nils Petter Gleditsch. 2005. "Monitoring Trends in Global Combat: A New Dataset of Battle Deaths." European Journal of Population 21(2-3):2-3.

Mankiw, Gregory. 1987. “The Optimal Collection of Seigniorage: Theory and Evidence." Journal of Monetary Economics 20(2):327-41.

Marcet, Albert, and Juan Nicolini. 2003. "Recurrent Hyperinflations and Learning." American Economic Review 93(5):1476-98.

Miguel, Edward, Shanker Satyanath, and Ernest Sergenti. 2004. "Economic Shocks and Civil Conflict: An Instrumental Variables Approach.” Journal of Political Economy 112(112):725-54.

Tavares, Juan 2003. "Does Foreign Aid Corrupt?” Economic Letters 79(1):99-106.

World Bank. 2006. World Development Statistics. Washington, D.C. 